8. Lewis P., Hilder P. Leaked: Cambridge Analytica's blueprint for Trump victory [Электронныйресурс]. URL: $\quad$ https://www.theguardian.com/uk-news/2018/mar/23/leaked-cambridge-analyticas-blueprint-fortrump-victory (дата обращения: 19.03.2018)

\title{
Марченко С.Е., Судоргин А.В. \\ Сравнительно-сопоставительный анализ перевода юридических терминов с немецкого и английского языков на русский
}

Донской государственный технический университет (Россия, Ростов-на-Дону)

doi: $10.18411 / s p c-26-04-2018-02$

idsp: 000001:spc-26-04-2018-02

Нами были проанализированы юридические тексты при переводе с английского и немецкого языков. При переводе с английского языка нами было выявлено 49 юридических терминов, при переводе с немецкого языка - 83 термина.

При переводе юридических терминов с английского языка наиболее часто используется калькирование - $24 \%$, второе место по частоте использования занимает дословный перевод - 17\%, на третьем месте стоит трансформация добавление, затем, как мы видим, самыми редкими способами перевода являются: перестановка (9\%), вариативное соответствие (6\%), нулевой перевод (4\%), стяжение $(4 \%)$, замены $(4 \%)$, экспликация (2\%), конверсия (2\%), синтаксическое уподобление $(2 \%)$ и антонимический перевод (2\%).

Самыми часто используемыми способами перевода юридических терминов в немецком языке являются: дословный перевод (46\%). Практически все термины в анализируемых текстах, выражены простыми словами и переводятся на русский язык аналогичными структурами. При этом подбирается термин-эквивалент для обеспечения однозначности и точности в языке перевода, а, следовательно, перевод происходит без применения трансформаций.

Развёртывание односложного термина (расщепление) (37\%). Данный способ перевода является наиболее частотным при передаче немецких лексем на русский язык. В силу различий структур немецкого и русского языка большинство немецких сложных слов, или композитов, в русском заменяются словосочетаниями с различными видами связи и варьирующимся количеством компонентов.

Добавление (5\%), калькирование (4\%), опущение $(3 \%)$, описательный перевод (3\%), функциональная замена $(1 \%)$, конверсия (1\%).

Теперь сравним полученные результаты:

Как мы видим для англоязычных и немецкоязычных текстов, в использовании приемов для перевода юридических терминов на русский язык имеются существенные различия.

Наиболее используемой трансформацией при переводе юридических терминов с английского языка является калькирование, в то время как при переводе с немецкого языка наиболее часто используется дословный перевод, который находится на втором месте по частоте использования в англоязычных текстах. В то время как второе место при переводе терминов с немецкого языка занимает прием развёртывание односложного термина (расщепление).

Это объясняется тем, что в английском и немецком языках существуют различия в словообразовании терминов. Особенностью юридических терминов в немецком языке является то, что практически большая часть терминов являются простыми однокомпонентными единицами, имеющими однозначный эквивалент в русском языке, остальная значимая часть терминов приходится на многокомпонентные немецкие существительные, которые в русском языке встречаются крайне редко и требуют при переводе расщепления на компоненты, чаще всего на словосочетания прил + сущ. В английском же языке ситуация другая, словарный состав английского языка, так же как и русского, не отличается разнообразием многокомпонентных терминов. Чаще всего 
юридические термины английского языка это производные словосочетания, образованные по морфологическому способу, которые представляют трудности при переводе и требуют различных преобразований.

В силу существующих различий между языками в процессе перевода неизбежно происходит потеря, добавление и искажение информации. Исходя из современных этнолингвистических моделей коммуникации, можно охарактеризовать перевод как создание на другом языке наиболее близкого по смыслу и стилю эквивалента подлинника.

В.Н.Комиссаров отмечает, что оценка качества перевода может производиться с большей или меньшей степенью детализации, для наиболее общей характеристики используются термины «адекватный», «эквивалентный», «точный», «буквальный», «вольный» и другие [1, с. 221].

Самый сложный момент в работе переводчика это использование разнообразных переводческих трансформаций. Л.С. Бархударов, Л.К. Латышев, Т.Р. Левицкая, А. М. Фитерман, В.Н. Комиссаров, Я.И. Рецкер подразделяют переводческие трансформации на лексические, грамматические, стилистические. Трансформации могут сочетаться друг с другом, принимая характер сложных комплексных трансформаций, при этом одни и те же трансформации могут иногда представлять собой спорный случай, их можно отнести к разным типам.

Как известно, английский, немецкий и русский язык имеют разную правовую природу, этот факт требует использования при переводе различных переводческих трансформаций. Одним из способов перевода с одного языка на другой является калькирование. Часть калек, возникших в связи с различными правовыми явлениями, используются для обозначения новых предметов и явлений юридической действительности, другая же служит названием уже известных предметов и явлений. Кроме калькирования также распространены метод заимствования, адаптация, часто используется метод конкретизации, там, где это возможно, наиболее эффективна такая грамматическая трансформация, как синтаксическое уподобление; в переведенных текстах широко представлены методы членение или объединение предложений, метод компенсации в виде добавления и опущения. С оговорками возможно использование метода грамматические замены, и метода экспликации. Но при переводе юридических текстов крайне нежелательны такие виды трансформаций, как их использование может привести к искажению содержания правового документа.

Перевод юридических текстов можно назвать одним из самых сложных и важных, так как он ориентирован на достижение определённого маркетингового успеха. Переводчик должен выступать как посредник между текстами на исходном языке и языке перевода. Адаптируя юридический текст с учётом специфики документации, переводчик может добиться большого успеха, т.е. большого коммуникативного эффекта.

$$
\text { *** }
$$

1. Комиссаров В.Н. Теория перевода (лингвистические аспекты). - М., 1990. - 134 с.

\section{Марченко С.Е., Фёдоров К.А. Анализ стилистических средств в языковой игре}

Донской государственный технический университет (Россия, Ростов-на-Дону)

doi: $10.18411 / s p c-26-04-2018-03$

idsp: 000001:spc-26-04-2018-03

Стилистические средства языка в качестве предпосылочного, исходно -данного материала выступают как совокупность изобразительно-выразительных средств в составе национального языка, а также стилистических приёмов. Однако можно говорить о стилистических средствах и в аспекте результата речевой и языковой 